\title{
The Correlation of Self-Leadership and Autonomy Among Students of Theological College in North Sumatera
}

\author{
Johanes Waldes Hasugian', May Rauli Simamora ${ }^{2}$, Nasib Tua Lumban Gaol ${ }^{3}$ \\ ${ }^{\text {IS }}$ ekolah Tinggi Teologi Sumatera Utara, Indonesia \\ 2,3 Institut Agama Kristen Negeri Tarutung, Indonesia \\ johaneswhasugian@gmail.com,may88simamora@gmail.com,nasib.t.lumbangaol@gmail.com
}

\begin{abstract}
College Students entering higher education will form new habits and require efforts to adjust to the demands of autonomy. Selfleadership is one of the adjustment strategies needed to achieve autonomy. This study aims to find out the relationship between self-leadership and student autonomy. The subject of the study was 211 college students of Theological College in North Sumatra. The data was collected using two scales, namely a self-leadership scale of 34 items with $a \alpha=0.91$ and an autonomy scale of 30 items with a $\alpha=0.87$. Pearson Product Moment's correlational analysis showed a correlation value of 0.679 with sig. $(2$-tailed $)=0.000$ $(p<0.01)$ which means there is a very significant positive relationship between self-leadership and autonomy. Students who develop self-leadership strategies, namely behavior-focused strategies, natural reward strategies constructive thought strategies will be able to direct themselves in acting as they see fit, making their own decisions and accounting for their own behavior. The coefficient of determination of $R$ Square is 0.462 which means the percentage of self-leadership variable contribution to increased autonomy is $46.2 \%$ and $53.8 \%$ is the contribution of other variables. The motivation and environment of students, the character of the tasks given, the competence of teaching lecturers, and the materials or courses taken by students may be able to contribute in student autonomy to the reach of academic achievement.
\end{abstract}

\section{Keywords}

autonomy; self-leadership; students of theological college

\section{Introduction}

College students face new things when entering college. For example, a flexible learning schedule which is different when sitting in high school (SMA). In addition, college students are required to be able to set their study schedules even though they are not in class. Differences in learning atmosphere and various other challenges lead college students to be able to deal with such situations. In the context of theological colleges, Novanto \& Yulianti (2015) state that college students are faced with new customs and cultures as well as challenges for them, including interacting with college students from different regions, the existence of spiritual disciplines set by the university, and involvement in ministry, study habits, attending lectures, searching for literature and learning resources, doing assignments, and completing exams as well as demographic and geographical conditions in theological colleges. All of these factors force them to be able to adapt well so that the learning atmosphere becomes comfortable.

College students are individuals who will leave adolescence to become independent adults. They are required to be free from dependence on their parents or other adults. The individual's ability to act independently, free from dependence on parents or other adults, is 
called autonomy. In addition, college students are required to be independent during their education (college world). As defined by Putri \& Suprapti (2014) that college students are individuals who have greater duties and responsibilities than a student, college students are required to be more initiative, active and independent in the world of education. Steinberg (2016) defines autonomy as the ability of individuals to behave according to their wishes, make their own decisions, and be able to take responsibility for their behavior. Independent college students can behave according to their wishes, make their own decisions, and are responsible for their behavior in the world of college. Independent college students are motivated to excel, namely to do everything well and have the fighting power to complete education (David, Matulessy \& Pratikto, 2014). Independent college students will be able to carry out academic activities without the involvement of parents or other adults.

Preliminary study data conducted by Alfinuha \& Nuqul (2017) showed that some college student complaints in carrying out academic activities were $34.61 \%$ due to the many activities and timing; $11.53 \%$ said they were too tired; each $7.69 \%$ stated the limited curfew and minimal facilities; and $3.85 \%$ of the remaining waiting time during academic activities. These complaints will not be felt if the student can manage himself well. Selfregulation by determining what activities should be done "now and in the future" requires special strategies.

A college student is a leader even though the person being led during his lectures is himself. Self-leadership is a person's ability to influence oneself and motivate oneself to perform tasks or work in increasing personal effectiveness and achieving certain desired goals (Manz, 1986). College students who can influence themselves and motivate themselves to do college assignments to improve their effectiveness will be able to achieve the various successes they want, namely completing their education.

During the lecture process, college students need leadership to be able to organize themselves. Self-leadership is not a goal, but an everyday process (Bryant, 2016). Selfleadership needs to be practiced every day. As has been proven by Agustina \& Bachroni (2012) that some people who take self-leadership training feel the benefits because it provides new knowledge and helps them to be enthusiastic about carrying out their duties, besides that self-leadership is very beneficial for self-development and needs to be done regularly. Likewise, college students who practice leadership themselves will be motivated to do the academic tasks of college students that are almost given every day. Samarenna \& Siahaan (2019) stated that the understanding of theological college students at 1 Timothy 4:12 will give students the ability to apply matters relating to leadership, which according to him requires a process of habituation to life until it becomes an inherent culture before it ends. students set an example for the congregation or the church in general.

\section{Review of Literature}

The need for autonomy may be related to self-leadership. Research conducted by Norris (2008) shows that the need for autonomy is not related to employee self-leadership. In other words, employees who have a high need for autonomy are not followed by a high level of leadership. Contrary to the research results of Norris (2008), research conducted by Shad, Sharbiyani, \& Abzari (2015) shows that employees need self-leadership to achieve autonomy. Shad, Sharbiyani, \& Abzari (2015) add that self-leadership plays a key role at all levels of the organization. Moving on from the lack of agreement between the two variables - self-leadership and autonomy, this study is very important to do.

In general, self-leadership is different from autonomy. Autonomy is the ability of individuals to behave according to their wishes, make their own decisions, and be able to 
account for their own behavior, which consists of emotional, behavioral, and cognitive aspects (Steinberg, 2016). Self-leadership as one's ability to influence oneself and motivate oneself to perform tasks or work in increasing personal effectiveness and achieving certain desired goals (Manz, 1986). Thus, autonomy describes a working condition (having wisdom about how and when to work), while self-leadership is a set of strategies for behavior and ways of thinking (Bäcklander et al., 2019).

According to Yani in Syardiansyah (2020) performance is a result of work achieved by a person in carrying out the tasks assigned to him based on skill, experience and sincerity as well as time. Werdhiastutie et al (2020) stated that the development of human resources should focus more on increasing productivity and efficiency. This can be realized because today's competition, especially among nations, is getting tougher and demands the quality of strong human resources as managers and implementers in an organization or institution.

Research conducted by Bäcklander et al. (2019) shows that self-leadership, both goal-centered strategies and thinking strategies, has a significant correlation with the autonomy of 0.14 and 0.13 ( $\mathrm{p}<0.01)$. In other words, a person's self-leadership is related to the autonomy he/she has. However, the interpretation of the correlation between selfleadership and autonomy is not explained. Thus, a study is needed to see how the relationship between the two variables is. Therefore, based on the description of the background of the problem, this study aims to investigate the relationship between selfleadership and college student autonomy at theological colleges in North Sumatra.

\section{Research Methods}

This study uses a quantitative approach. The participants involved were college students of the theological college in North Sumatra. Determination of the sample is done by referring to Creswell (2015) through a convenience sampling approach (based on the objectives of the researcher and the affordability of the researcher to the participants). Thus, from this approach, as many as 211 college students became respondents in this study.

The process of collecting data from participants used two instruments. First, Student Self-Leadership to measure student self-leadership. This instrument is modified from the Teacher Self-Leadership scale (Simamora and Afiatin, 2017) which was developed based on Manz's (1986) theory where self-leadership has three aspects, namely behavior-focused, natural rewards and constructive thinking (constructive thought). The total items that have been used in this scale are 39 items consisting of 25 favorite items and 14 unfavorable items. Furthermore, these 39 items were tested on 40 test respondents so that 34 valid items were obtained and 5 items were declared invalid with a Cronbach's Alpha coefficient of 0.91. Second, the scale of student autonomy to reveal student autonomy. This instrument was prepared by the researcher by referring to the theory of Steinberg (2016). The total items on the autonomy scale are 40 items consisting of 23 favorite items and 17 unfavorable items. Furthermore, 40 autonomy scale items were tested on 40 respondents who have the same characteristics as the sample so that 30 valid items were obtained and 10 items were declared invalid with a Cronbach's Alpha coefficient of 0.87 .

The two research instruments used consisted of two types of statements, namely favorable items and unfavorable items. The scoring of the favorite items uses a Likert scale of 5 answer categories, namely 1 (Highly Not Appropriate); 2 (Not Appropriate); 3 (Neutral), 4 (Agree); and 5 (Very Appropriate). While scoring on unfavorable items uses a 
Likert scale of 5 answer categories, namely 1 (Very Appropriate); 2 (Appropriate); 3 (Neutral); 4 (Not Appropriate); and 5 (Highly Inappropriate).

After conducting trials on the compiled scale, the Cronbach's Alpha coefficient value was 0.87 on the autonomy scale and 0.91 on the self-leadership scale. Thus, both scales are declared good and can be used for research. To analyze the data, Pearson Product Moment correlation analysis is used to find out the trend or pattern for two or more variables and find linear or nonlinear relationships and positive or negative directions (Creswell, 2015). Correlational analysis in this study was carried out with the help of SPSS (Statistical Package for Social Sciences) 25.

\section{Results and Discussion}

There were 211 college students involved in this research. They are college students who are registered at several theological in North Sumatra and are willing to voluntarily become research subjects. The college students studied consisted of $81.5 \%$ female and $18.5 \%$ male (Table 1). Most of the subjects were in the third semester, namely 70 college students and most of the college students came from the Christian Religious Education Study Program, which was 150 people or $71.1 \%$.

Table 1. Participant Information $(\mathrm{N}=211)$

\begin{tabular}{lcccc}
\hline \multicolumn{1}{c}{ Variable } & $\boldsymbol{n}$ & $\%$ & Mean & SD \\
\hline Gender & & & 1.8 & 0.38 \\
\hline \multicolumn{1}{c}{ a. Man } & 39 & 18.5 & & \\
\hline b. Woman & 172 & 81.5 & & \\
\hline Semester & & & 2.43 & 1.16 \\
\hline a. I & 51 & 24.2 & & \\
\hline b. III & 70 & 33.2 & & \\
\hline c. V & 49 & 23.2 & & \\
\hline d. VII & 29 & 13.7 & & \\
\hline e. IX & 12 & 5.7 & & \\
\hline Study program & & & 2.13 & 0.71 \\
\hline a. Christian Education & 24 & 11.4 & & \\
Management & & & & \\
\hline b. Pastoral Counseling & 150 & 71.1 & & \\
\hline c. Christian Religious & 24 & 11.4 & & \\
Education & & & & \\
\hline d. Theology & 11 & 5.2 & & \\
\hline e. Church Music Education & 2 & 0.9 & & \\
\hline
\end{tabular}

Before testing the hypothesis, the classical assumption test was first tested, namely the normality test and linearity test. The normality test in this study was carried out on both variables using the One-Sample Kolmogorov-Smirnov (K-S) test with the help of SPSS (Statistical Package for the Social Sciences) 25 For Windows. The results of the normality test of the two variables can be seen in Table 2. The results show that the self-leadership variable has a significance value of $0.055(\mathrm{p}>0.05)$, which means that it is normally distributed and the autonomy variable has a significance value of 0.200 ( $p>0.05)$, which is also means normally distributed. 
Table 2. Normality and Linearity Test Results

\begin{tabular}{lccccccr}
\hline \multirow{2}{*}{ Variable } & \multicolumn{3}{c}{$\begin{array}{c}\text { Normality Test } \\
\text { Kolmogorov-Smirnov }\end{array}$} & \multicolumn{3}{c}{ Linearity Test } \\
& Statistic & df & Sig. & Statistic & df & Sig. \\
\cline { 2 - 6 } & 0.040 & 211 & 0.200 & 1.104 & 60 & 0.312 \\
\hline Autonomy & 0.061 & 211 & 0.055 & & & \\
\hline Self-leadership & & & & &
\end{tabular}

Table 2 also shows the value of the linearity test result of 1.104 with a significance of 0.312 ( $>0.05$ ), which means that the two variables have a linear relationship. Thus, both classical assumptions are met, namely normal and linear distribution so that it can be continued in the next test, namely hypothesis testing.

Table 3. Correlation results between self-leadership and autonomy

\begin{tabular}{cccc}
\hline Variable & Self-Leadership & & \\
\cline { 2 - 4 } & Pearson Correlation & P-value & R-Square \\
\hline Autonomy & 0.679 & 0.000 & 0.462 \\
\hline
\end{tabular}

The results of the correlation of the two variables in this study are shown by the Pearson Correlation coefficient value in Table 3 which is 0.679 with sig.(2-tailed) $=0.000$ $(\mathrm{p}<0.01)$. That is, there is a very significant positive relationship between the autonomy variable and the self-leadership variable. According to Field (2018), the strong relationship between the two variables that are in the range is in the medium category. The correlation results indicate that the proposed research hypothesis, namely the existence of a significant positive relationship between self-leadership and autonomy, is declared acceptable. This means that a high level of self-leadership is followed by a high level of individual autonomy. Meanwhile, to see the effective contribution of the self-leadership variable to the autonomy variable, it is known through the value of the coefficient of determination $\mathrm{R}$ Square which in this study is 0.462 . That is, the percentage contribution of the selfleadership variable to the increase in autonomy is $46.2 \%$ and $53.8 \%$ is the contribution of other variables.

The results of the study on 211 college students at theological students in North Sumatra who were willing to be involved in the study found that there was a positive relationship between self-leadership and autonomy. It can be interpreted that college students who have high self-leadership strategies will also show high scores on autonomy. The results of this study are in line with research conducted by Shad, Sharbiyani, \& Abzari (2015) which states that to achieve autonomy, a self-leadership strategy is needed. In addition, other studies have proven that self-leadership strategies, namely goal-centered strategies and thinking strategies have a correlation with autonomy (Bäcklander et al., 2019). Thus, it is clear that college students who have self-leadership will motivate and influence themselves to behave according to their wishes, make decisions, and be able to take responsibility for their own behavior.

College tudents must have self-leadership to achieve autonomy. Manz (1986) explains that self-leadership consists of three aspects or strategies, namely behaviorfocused strategies, natural reward strategies, and constructive thinking strategies. The assignments are so many and have a certain time limit will challenge college students to have these strategies. College students who have a behavior-focused strategy will direct themselves to achieve success in managing behaviors related to lecture assignments that are needed even though they are not fun. The strategy used is self-observation, namely 
examining one's own behavior to increase awareness of when and why certain behaviors occur so as to determine which behaviors will be changed, improved or eliminated (Houghton, Dawley and DiLiello, 2012; Mansor, 2012). Darus and Dali, 2013). Developing and implementing specific goals and rewarding yourself for your work are also strategies that can help achieve success.

College students who have a natural reward strategy will create positive perceptions and experiences regarding the tasks that must be completed and enjoy the task. This makes college students feel that they have the ability to do something, are able to control themselves and understand their goals. There are many simple things that college students can do to create positive perceptions and experiences, such as tidying up or decorating the study room, exercising while thinking about a difficult task or listening to music while studying. These activities can make the task more enjoyable to do.

College students who have a constructive thinking strategy will form a constructive mindset and get used to positive thinking that can affect performance or self-achievement. College students identify themselves and find useless beliefs that can cause psychological disorders so that more rational and effective thinking can be formed. Imagining the success that is in sight of a task even though it has not been done will help oneself complete the task. In addition, discuss with yourself through personal dialogue (self-talk) to replace or eliminate negative and pessimistic thoughts into positive and optimistic thoughts about the tasks at hand. All of the above strategies are carried out individually who direct themselves to behave according to their wishes, make their own decisions, and are able to take responsibility for their own behavior (Steinberg, 2016) so that they can be free from dependence on parents or other adults.

The contribution of the self-leadership variable to the increase in autonomy in this study was $46.2 \%$, while $53.8 \%$ was the contribution of other variables. Kemala (2016) identified several factors that can affect autonomy, namely motivation, environment, assigned tasks, teachers, and materials. Some of these factors are weaknesses in this study. The motivation to take courses at religious universities related to the profile of graduates, the student environment such as family, lecturers or friends, the task load or the level of difficulty of the material given to college students needs to be investigated as factors that can affect student autonomy.

\section{Conclusion}

The results of this study indicate that there is a very significant positive relationship between self-leadership and autonomy among theological students in North Sumatra. From this correlation, it is evident that the more college students develop self-leadership strategies, the more college students can increase their autonomy. Based on the results of the study, it was found that the contribution of self-leadership in increasing autonomy was $46.2 \%$. These results indicate that college students need to practice self-leadership personally as a daily habit in undergoing lectures at theological college. This selfleadership exercise will form an independent personality so that college students can maximize academic performance.

There are several other factors that may support student autonomy in addition to selfleadership. Therefore, it is recommended for further researchers to investigate the relationship between motivation, student environment, the character of the tasks given, the teaching competence of lecturers, and the material or courses taken by college students with student autonomy. 


\section{References}

Agustina, I. and Bachroni, M. (2012) 'Pengaruh Pelatihan Kepemimpinan Diri Untuk Meningkatkan Kepuasan Kerja Karyawan', Jurnal Intervensi Psikologi (JIP), 4(2), pp. 231-252. doi: 10.20885/intervensipsikologi.vol4.iss2.art6.

Alfinuha, S. and Nuqul, F. L. (2017) 'Bahagia dalam Meraih Cita-cita: Kesejahteraan Subjektif Mahasiswa Teknik Arsitektur Ditinjau dari Regulasi Emosi dan Efikasi Diri', Psikohumaniora: Jurnal Penelitian Psikologi, 2(1), pp. 12-28.

Bäcklander, G. et al. (2019) 'Navigating the Activity-Based Working Environment Relationships of Self-Leadership, Autonomy and Information Richness with Cognitive Stress and Performance', Scandinavian Journal of Work and Organizational Psychology, 4(1). doi: 10.16993/sjwop.58.

Bryant, A. (2016) Self Leadership - 12 Powerful Mindsets \& Methods to Win in Life \& Business. Singapore. Available at: https://02f0a56ef46d93f03c9022ac5f107621879d5667e0d7ed595bdb.ssl.cf2.rackcdn.com/sites/10980/uploads/140 82/w_andr0120161213-5208-1joxihy.pdf.

Creswell, J. (2015) Riset Pendidikan: Perencanaan, Pelaksanaan, dan Evaluasi Riset Kualitatif dan Kuantitatif. Kelima, Pustaka Pelajar. Kelima. Yogyakarta. Available at: https://togamas.com/detail-buku-7239=Riset_Pendidikan_Edisi_Kelima (Accessed: 11 June 2020).

David, L. E. V., Matulessy, A. and Pratikto, H. (2014) 'Pola Asuh Demokratis, Kemandirian dan Motivasi Berprestasi pada Mahasiswa', Persona:Jurnal Psikologi Indonesia, 3(01), pp. 65-70. doi: 10.30996/persona.v3i01.370.

Field, A. (2018) Exploring Statistics Using IBM SPSS Statistics.

Houghton, J. D., Dawley, D. and DiLiello, T. C. (2012) 'The Abbreviated Self-Leadership Questionnaire [ASLQ]: A more concise measure of self-leadership.', International Journal of Leadership Studies, 7(2), pp. 216-232.

Kemala, Z. (2016) 'An Analysis of Factors Influencing the Autonomous Learners in Learning English', Eltin, 4(I), pp. 11-20.

Mansor, A., Darus, A. and Dali, M. H. (2013) 'Mediating effect of self-efficacy on selfleadership and teachers' organizational citizenship behavior: A conceptual framework', International Journal of Economics Business and Management Studies, 2(1), pp. 1-11.

Manz, C. C. (1986) 'Self-Leadership: Toward an Expanded Theory of Self-Influence Processes in Organizations', Academy of Management Review. Academy of Management, 11(3), pp. 585-600. doi: 10.5465/amr.1986.4306232.

Norris, S. E. (2008) 'An Examination of Self-Leadership', Emerging Leadership Journeys, 1(2), pp. 43-61.

Novanto, Y. and Yulianti, L. (2015) 'Faktor-faktor yang Berkaitan dengan Prestasi Akademik Mahasiswa Sekolah Tinggi Teologi "X", in, pp. 0-16. Available at: https://www.researchgate.net/profile/Yusak-Novanto-

2/publication/283352540_FAKTOR_-

_FAKTOR_YANG_BERKAITAN_DENGAN_PRESTASI_AKADEMIK_MAHAS ISWA_SEKOLAH_TINGGI_TEOLOGI_X/links/5636c7e908aeb786b703f3de/FAK TOR-FAKTOR-YANG-BERKAITAN-DENGAN-PRESTASI-AKADEMIKMAHA.

Putri, D. A. and Suprapti, V. (2014) 'Hubungan antara Self-Efficacy dengan Subjective Well-Being pada Mahasiswa Baru Politeknik Elektronika Negeri Surabaya ( PENS ) yang Kos', Psikologi Industri dan Organisasi, 3(3), pp. 144-150. 
Samarenna, D. and Siahaan, H. E. R. (2019) 'Memahami dan Menerapkan Prinsip Kepemimpinan Orang Muda Menurut 1 Timotius 4:12 bagi Mahasiswa Teologi', BIA': Jurnal Teologi dan Pendidikan Kristen Kontekstual, 2(1), pp. 1-13. doi: 10.34307/b.v2i1.60.

Shad, F., Sharbiyani, A. and Abzari, M. (2015) 'Studying The Relation Between SelfLeadership With Job Satisfaction And Performance Improvement', Global Journal of Human Resource Management, 3(3), pp. 39-57.

Simamora, M. R. and Afiatin, T. (2017) Peran Kepemimpinan Diri terhadap Empati Guru dengan Kesejahteraan Sekolah sebagai Mediator. (Tesis tidak diterbitkan). Fakultas Psikologi Universitas Gadjah Mada, Yogyakarta.

Steinberg, L. (2016) Adolescence. 11th edn. New York: McGraw-Hill Education.

Syardiansah, et al. (2020). The Effect of Job Satisfaction and Organizational Culture on Employee Performance of the Royal Hotel in East Aceh District. Budapest International Research and Critics Institute-Journal (BIRCI-Journal). P. 849-857.

Werdhiastutie, A., et al. (2020). Achievement Motivation as Antecedents of Quality Improvement of Organizational Human Resources. International Research and Critics Institute-Journal (BIRCI-Journal). P. 747-752. 